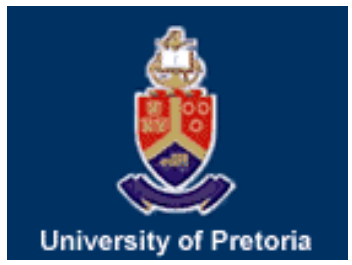

University of Pretoria

Department of Economics Working Paper Series

The Impact of the International Economic Crisis on Child Poverty in South

Margaret Chitiga

University of Pretoria

Bernard Decaluwé

Laval University

Ramos Mabugu

Financial and Fiscal Commission

Helene Maisonnave

Financial and Fiscal Commission

Véronique Robichaud

Laval University

Debra Shepherd

Stellenbosch University

Servaas van der Berg

Stellenbosch University

Dieter von Fintel

Stellenbosch University

Working Paper: 2010-15

June 2010

Department of Economics

University of Pretoria

0002, Pretoria

South Africa

Tel: +27 124202413 


\title{
The impact of the international economic crisis on child poverty in South Africa
}

Margaret Chitiga, Department of Economics, University of Pretoria,

Bernard Decaluwé, Laval University (Québec) and PEP network,

Ramos Mabugu, Financial and Fiscal Commission, South Africa, corresponding author, Ramosm@ffc.co.za

Helene Maisonnave, Financial and Fiscal Commission, South Africa and Joint Research Center, IPTS, Seville,

Véronique Robichaud, Laval University (Québec) and PEP network,

Debra Shepherd, Department of Economics, University of Stellenbosch,

Servaas Van der Berg, Department of Economics, University of Stellenbosch, and Dieter von Fintel, Department of Economics, University of Stellenbosch

\begin{abstract}
This paper reports on a study to provide insights into the magnitude of the shocks associated with the recent global economic crisis in macroeconomic terms in South Africa, the country's capacity to withstand or cushion these shocks, and the extent of fragility in terms of poverty levels and child wellbeing. The analysis combines macroeconomic and micro-economic tools to assess the extent of the crisis' impact on the country. The study finds that the poverty headcount ratio increases little in the moderate crisis scenario, but substantially under the severe scenario. However, under both scenarios there is a relatively successful return to close to the business as usual trend. It is important to note though that under both scenarios, more poverty sensitive measures (the poverty gap ratio and the poverty severity ratio) decline more, and remain in negative territory longer, showing that the major impact of the crisis is on the poorest, and that this impact is most difficult to overcome.
\end{abstract}




\section{Introduction}

The United States of America subprime mortgage crisis which began in August 2007 degenerated into a full-scale global financial crisis between August and October 2008. After a lag, the crisis began to be felt by South Africa. The country has especially been affected by the sharp fall in demand for its export products, the fall in prices of key export commodities and falling foreign investment. The economy was recently plunged into a recession for the first time in 17 years and its macroeconomic forecasts have had to be revised downwards substantially ${ }^{1}$. The declining growth has potentially negative implications for incomes, employment, investment and on social programmes partly through the slowdown's effect on tax revenues for government.

Poverty in the country is much higher than one would expect in a country with its level of per capita gross domestic product (GDP). There is a high degree of inequality in the country, and it has its origins in the apartheid policies of the past. Child poverty, in turn, is still much higher than poverty amongst adults. There is widespread concern that the global economic crisis may have exacerbated the situation. This makes it imperative to deal with the phenomenon of child poverty as a specific issue. This is necessary to prevent large numbers of children growing up in dire circumstances that can prevent them from developing their potential. Economically, childhood poverty also leaves a mark in terms of poor human capital and lower productivity in later life, thus creating the risk of a vicious cycle of poverty. To ensure that upward mobility of those born into poor families is possible, South Africa needs to create conditions that will reduce child poverty.

This paper (to our knowledge the first of its kind) studies the impact of the world economic crisis on child poverty in South Africa. It does this by linking a macroeconomic Computable General Equilibrium (CGE) model to micro-economic analysis in order to identify the channels through which economic performance may impact on child poverty and to estimate its likely magnitude.

The remainder of the paper is divided into four sections. Section 2 describes the data used for the model and the profile of child poverty while section 3 discusses the model and simulations. Section 4 reports and discusses results of the various simulations and section 5 concludes.

\footnotetext{
${ }^{1}$ Gross domestic product at market prices quarter on quarter growth figures for South Africa reveal that the economy experienced three quarters of negative growth (from the fourth quarter of 2008 to the second quarter of 2009). The definition of a recession is when a country experiences two successive quarters of negative quarter on quarter growth on a seasonally adjusted basis.
} 


\section{Data and the profile of child poverty}

The Social Accounting Matrix (SAM) used for the CGE model is based on the 2005 Supply and Use tables obtained from Statistics South Africa and other national data sets from various sources such as the Reserve Bank. The SAM has 54 activities and 54 commodities; two factors of production, labour and capital; four agents (households, enterprises, government and the rest of world); and two accumulation accounts (change in inventories and gross fixed capital formation).

Trade parameters are obtained from Gibson (2003) while low-bound export supply and demand elasticities are obtained from Behar and Edwards (2004). To our knowledge, estimates for parameters used in production functions and in households' demand functions are not available for South Africa. Therefore values from the literature surveyed by Annabi et al. (2006) were used.

One of the main transmission channels of the crisis is a decrease in export and import prices and demand. Table 1 presents trade relations between South Africa and the rest of the world in 2005. It specifies the import penetration rate as well as the sectoral share of imports in total imports. Moreover, it details the sectoral export intensity rates measured as a share of exports in production in each sector and the share of each sector's exports in total exports.

Table 1 : Structure of South African trade (tradables) (\%)

\begin{tabular}{|l|c|c|c|c|}
\hline Sectors & $\begin{array}{c}\text { Exports } \\
\text { intensity rate as } \\
\text { a share of total } \\
\text { sectoral } \\
\text { production (\%) }\end{array}$ & $\begin{array}{c}\text { Sectoral Exports } \\
\text { shares as a proportion } \\
\text { of total exports (\%) }\end{array}$ & $\begin{array}{c}\text { Imports } \\
\text { penetration rate as } \\
\text { a share of total } \\
\text { sectoral supply (\%) }\end{array}$ & $\begin{array}{c}\text { Sectoral Imports } \\
\text { share as a } \\
\text { proportion of total } \\
\text { imports (\%) }\end{array}$ \\
\hline $\begin{array}{l}\text { Agriculture, forestry } \\
\text { \& fishing }\end{array}$ & 21,89 & 4,14 & 5,84 & 1,09 \\
\hline Coal mining & 48,96 & 5,01 & 4,47 & 0,26 \\
\hline $\begin{array}{l}\text { Gold \& uranium ore } \\
\text { mining }\end{array}$ & 98,65 & 6,58 & 0,53 & 0,00 \\
\hline Other mining & 50,65 & 12,82 & 30,55 & 11,08 \\
\hline Food & 8,50 & 2,38 & 6,02 & 2,52 \\
\hline Beverages \& tobacco & 22,16 & 2,29 & 2,54 & 0,42 \\
\hline
\end{tabular}




\begin{tabular}{|c|c|c|c|c|}
\hline Textiles & 16,58 & 0,70 & 14,40 & 1,15 \\
\hline Wearing apparel & 12,89 & 0,54 & 11,41 & 1,27 \\
\hline $\begin{array}{l}\text { Leather \& leather } \\
\text { products }\end{array}$ & 35,87 & 0,44 & 17,45 & 0,26 \\
\hline Footwear & 5,12 & 0,05 & 20,39 & 0,72 \\
\hline $\begin{array}{l}\text { Wood \& wood } \\
\text { products }\end{array}$ & 12,94 & 0,61 & 8,98 & 0,50 \\
\hline $\begin{array}{l}\text { Paper \& paper } \\
\text { products }\end{array}$ & 15,95 & 1,45 & 8,81 & 0,96 \\
\hline $\begin{array}{l}\text { Printing, publishing } \\
\& \text { recorded media }\end{array}$ & 4,89 & 0,22 & 14,78 & 1,10 \\
\hline $\begin{array}{l}\text { Coke \& refined } \\
\text { petroleum products }\end{array}$ & 17,39 & 2,59 & 5,34 & 1,30 \\
\hline Basic chemicals & 30,81 & 4,60 & 21,66 & 4,32 \\
\hline $\begin{array}{l}\text { Other chemicals \& } \\
\text { man-made fibres }\end{array}$ & 11,54 & 2,09 & 12,53 & 3,95 \\
\hline Rubber products & 23,54 & 0,48 & 22,56 & 0,91 \\
\hline Plastic products & 5,54 & 0,36 & 9,13 & 0,73 \\
\hline $\begin{array}{l}\text { Glass \& glass } \\
\text { products }\end{array}$ & 11,56 & 0,19 & 12,64 & 0,29 \\
\hline $\begin{array}{l}\text { Non-metallic } \\
\text { minerals }\end{array}$ & 7,71 & 0,46 & 11,18 & 0,87 \\
\hline Basic iron \& steel & 62,48 & 10,48 & 11,56 & 1,24 \\
\hline $\begin{array}{l}\text { Basic non-ferrous } \\
\text { metals }\end{array}$ & 47,03 & 2,94 & 19,44 & 1,10 \\
\hline $\begin{array}{l}\text { Metal products } \\
\text { excluding machinery }\end{array}$ & 19,02 & 1,79 & 13,88 & 1,66 \\
\hline $\begin{array}{l}\text { Machinery \& } \\
\text { equipment }\end{array}$ & 67,47 & 7,11 & 35,35 & 12,83 \\
\hline Electrical machinery & 13,23 & 0,97 & 17,18 & 2,25 \\
\hline $\begin{array}{l}\text { Television, radio \& } \\
\text { communication } \\
\text { equipment }\end{array}$ & 53,25 & 0,88 & 39,74 & 5,26 \\
\hline $\begin{array}{l}\text { Professional \& } \\
\text { scientific equipment }\end{array}$ & 84,86 & 0,90 & 30,42 & 2,40 \\
\hline $\begin{array}{l}\text { Motor vehicles, parts } \\
\& \text { accessories }\end{array}$ & 20,46 & 6,72 & 23,08 & 15,32 \\
\hline $\begin{array}{l}\text { Other transport } \\
\text { equipment }\end{array}$ & 27,40 & 0,68 & 33,73 & 3,24 \\
\hline Furniture & 48,87 & 1,71 & 9,48 & 0,56 \\
\hline Other industries & 18,34 & 1,94 & 12,97 & 3,01 \\
\hline $\begin{array}{l}\text { Electricity, gas \& } \\
\text { steam }\end{array}$ & 0,96 & 0,11 & 0,02 & 0,00 \\
\hline Water supply & 0,00 & 0,00 & 0,00 & 0,00 \\
\hline Building construction & 0,05 & 0,02 & 0,26 & 0,09 \\
\hline $\begin{array}{l}\text { Wholesale \& retail } \\
\text { trade }\end{array}$ & 1,21 & 1,01 & 0,06 & 0,05 \\
\hline $\begin{array}{l}\text { Catering \& } \\
\text { accommodation } \\
\text { services }\end{array}$ & 21,33 & 1,45 & 22,81 & 2,49 \\
\hline Railway transport & 15,39 & 0,58 & 9,16 & 0,35 \\
\hline Road transport & 7,42 & 1,93 & 1,55 & 0,37 \\
\hline $\begin{array}{l}\text { Transport via } \\
\text { pipeline }\end{array}$ & 16,04 & 0,04 & 0,00 & 0,00 \\
\hline Water transport & 13,52 & 0,53 & 31,67 & 2,80 \\
\hline
\end{tabular}




\begin{tabular}{|l|c|c|c|c|}
\hline Air transport & 20,37 & 0,65 & 32,11 & 2,18 \\
\hline $\begin{array}{l}\text { Transport support } \\
\text { services }\end{array}$ & 9,87 & 0,80 & 12,74 & 1,21 \\
\hline Communication & 7,01 & 2,21 & 6,13 & 2,00 \\
\hline Finance \& insurance & 6,26 & 0,61 & 9,71 & 1,40 \\
\hline Business services & 3,90 & 4,61 & 1,70 & 0,20 \\
\hline $\begin{array}{l}\text { Medical, dental \& } \\
\text { other health \& } \\
\text { veterinary services }\end{array}$ & 0,60 & 0,11 & 6,47 & 2,29 \\
\hline $\begin{array}{l}\text { Community, social \& } \\
\text { personal services }\end{array}$ & 3,69 & 1,22 & & \\
\hline
\end{tabular}

Source: Own computations from SAM (2005)

From the Table above, it can be seen that gold (98\% of its production), scientific equipment (84\%) or machinery and equipment $(67 \%)$ heavily rely on exports. A decrease in world demand or an increase in international prices for these commodities will thus have a huge impact on the balance of payments and on economic activity. In the same way, some commodities such as radio and equipment (39\%) and other mining (30\%) rely disproportionately more on imports. For these sectors, a decrease in international prices will stimulate imports and increase competition from foreign suppliers on domestic market. Since South Africa exports most of its mineral and precious metals, together accounting for $40.9 \%$ of total exports, an external shock on mineral prices would likely have strong effects on the economy.

The 2005 GDP projections for South Africa were used to build the Business As Usual (BAU) scenario. To replicate GDP growth rate projections, population growth and capital accumulation were combined with an endogenous rate of growth of total factor productivity. Investments by destination as well as depreciation rates by activities were taken from the South African Reserve Bank. Given that official data projected a smaller growth for population than what was anticipated for capital, the BAU scenario shows a decrease in unemployment. Moreover, as production factors become more efficient, prices decrease (in real terms). 
To derive a profile of child poverty, we set a poverty line at the 40th percentile of household per capita income in the 2005 Incomes and Expenditure Survey (IES) ${ }^{2}$. Naturally, there are important issues about the appropriate poverty line and about whether it would make a difference if some adult equivalent scale were used instead of per capita income. However, we have dealt with that in another work (Streak, Yu and Van der Berg, 2009). We concluded that the profile of poverty is not really affected by using any adult equivalent scale and that there is stochastic poverty dominance across most dimensions ${ }^{3}$. In other words, the poverty profile would not change much if an alternative poverty line or an alternative poverty measure to the headcount ratio were used. Therefore, using per capita income rather than adult equivalent income shows that our findings on the insensitivity of the child poverty profile to the choice of adult equivalence scale support the argument of Woolard and Leibbrandt (2006). This is that one may as well use the simple per capita method of profiling poverty in South Africa and testing its robustness to alternative poverty lines.

Table 2 presents the profile of child poverty. Poor households tend to be larger. Therefore, the poverty headcount for the population as a whole is $52.9 \%$. However, poorer households have a disproportionate number of children: $65.5 \%$ of children are amongst the poor (this converts into 11.8 million poor children) ${ }^{4}$ as against only $45.2 \%$ of the adult population. Moreover, similar differences between adult and child poverty apply for the depth and severity of poverty. In fact, the proportional differentials are larger, indicating that children's share of the poverty headcount rises if lower poverty lines are used because of more severe poverty amongst children compared to adults.

With respect to age, Table 2 illustrates that the poverty headcount and poverty shares based on the headcount are highest amongst the youngest age cohort, followed by children aged between 5 and 14 and between 15 and 17. The profile also confirms the racial dimension of child poverty, which is much higher amongst black children and high amongst coloured children 5 . The poverty depth and severity measures are also far higher for children from these groups. There is little gender difference in child

\footnotetext{
${ }^{2}$ The line is arbitrary, but agrees with what a number of other authors have used, particularly in assessing the effect of the adult equivalence scale.

${ }^{3}$ The exception is the provinces. There is no stochastic poverty dominance across this dimension, thus there are some provinces where the poverty ranking would change if another poverty line or another poverty measure were used.

${ }^{4}$ This level, though somewhat arbitrary considering the equally arbitrary choice of the poverty line, can be seen in the context of findings based on earlier data sets that used similar poverty cut offs. The National Institute for Economic Policy (NIEP) measurement study (1996), which is based on the Project for Statistics on Living Standards and Development (PSLSD) of 1993, and which used the old Organisation for Economic Cooperation and Development (OECD) Adult Equivalent Scale (AES), found the poverty headcount amongst children aged between birth and 4 years of age to be $60 \%$. Woolard (2002), using the October Household Survey (OHS) 1999, a welfare indicator of adult equivalent income and a Cutler and Katz (1992) type AES with the child cost parameter set at 0.6 and economies of scale parameter at 0.9 , found it to be $59.2 \%$ amongst children aged between birth and 17 and 59.3\% amongst children aged between birth and 6 . Thus the poverty findings here are not all that different from those in previous studies, whereas there is somewhat less child poverty if the suggested Statistics South Africa (StatsSA) poverty line is used.

${ }^{5}$ Defining households by colour is one of the popular ways used in South Africa. Including the race-based definition is rooted in the apartheid period policies. The 'black' people of South Africa are natives of the country. They include mainly the Zulu, Xhosa, Ndebele, Swazi, Sotho-Tswana, Tsonga and the Venda language groups. 'White' people are mainly descendents of the colonial immigrants of Dutch, German, French Huguenot and British origin. 'Coloureds' are most commonly people of a mixed race or descendants of the Khoi and San. 'Asians' are mainly people of Indian descent (South Africa. Info, 2007).
} 
poverty. Child poverty is still more prevalent, deeper and more severe in rural areas nearly two thirds of children identified as poor live in rural areas. Its rural face is the most prominent feature of child poverty in South Africa, and this especially applies when the depth and severity of poverty are considered: the rural poor are further below this poverty line than the urban poor are, and the share of the rural child poverty headcount thus rises as the poverty line is set lower. There is large variation across provinces in child poverty.

Though the poverty incidence is highest in Limpopo, the poverty share of the more populous provinces is larger. Kwazulu-Natal and the Eastern Cape together have $46 \%$ of the poor children. The rankings for the poverty severity measure are slightly different from those on the depth and headcount measures. This indicates that stochastic poverty dominance does not always hold. Kwazulu-Natal has the most severe poverty, while it has the second highest poverty depth and the third highest poverty headcount. Limpopo ranks third in terms of the severity and depth measures, but first on the poverty headcount measure. Western Cape is the best performer on all three of the Foster-Greer-Thorbecke (FGT) poverty measures - it has the lowest child poverty headcount rate (P0) ${ }^{6}$, the lowest depth of child poverty (also known as the child poverty gap ratio $[\mathrm{P} 1])^{7}$ and the lowest child poverty severity ratio (P2) ${ }^{8}$.

Table 2 : Poverty profile for children using per capita income as the welfare measure and with the poverty line set at $40^{\text {th }}$ percentile of households

\begin{tabular}{|c|c|c|c|c|c|c|c|c|}
\hline & \multicolumn{5}{|c|}{ Child poverty (0-17 years) } & \multicolumn{3}{|c|}{ Adult poverty } \\
\hline & \multicolumn{3}{|c|}{$\begin{array}{c}\mathrm{P}_{0} \\
\text { Poverty headcount rate }\end{array}$} & \multirow{2}{*}{$\begin{array}{c}P_{1} \\
\text { Poverty } \\
\text { depth } \\
\text { measure }\end{array}$} & \multirow{2}{*}{$\begin{array}{c}\mathrm{P}_{\mathbf{2}} \\
\text { Poverty } \\
\text { severity } \\
\text { measure }\end{array}$} & \multirow{2}{*}{$\begin{array}{c}P_{0} \\
\text { Poverty } \\
\text { head- } \\
\text { count } \\
\text { rate } \\
\text { Rate (\%) }\end{array}$} & \multirow{2}{*}{$\begin{array}{c}\mathrm{P}_{1} \\
\text { Poverty } \\
\text { depth } \\
\text { measure }\end{array}$} & \multirow{2}{*}{$\begin{array}{c}P_{2} \\
\text { Poverty } \\
\text { severity } \\
\text { measure }\end{array}$} \\
\hline & $\begin{array}{c}\text { Rate } \\
(\%)\end{array}$ & $\begin{array}{c}\text { Share } \\
(\%)\end{array}$ & Number & & & & & \\
\hline \multicolumn{9}{|l|}{ Age } \\
\hline $0-4$ & 66.1 & 26.0 & 3066509 & 0.336 & 0.213 & & & \\
\hline $5-14$ & 65.7 & 56.5 & 6681507 & 0.343 & 0.202 & & & \\
\hline $15-17$ & 63.8 & 17.5 & 2067609 & 0.332 & 0.203 & & & \\
\hline 0-17 (all children) & 65.5 & 100.0 & 11822544 & 0.328 & 0.205 & & & \\
\hline $18+$ (all adults) & & & & & & 45.2 & 0.213 & 0.126 \\
\hline \multicolumn{9}{|c|}{ Racial group } \\
\hline Black & 72.5 & 93.9 & 11100826 & 0.375 & 0.232 & 54.4 & 0.261 & 0.156 \\
\hline Coloured & 41.3 & 5.3 & 623412 & 0.167 & 0.093 & 30.1 & 0.110 & 0.057 \\
\hline Asian & 24.2 & 0.7 & 76137 & 0.093 & 0.052 & 13.7 & 0.049 & 0.027 \\
\hline White & 2.0 & 0.2 & 18081 & 0.012 & 0.008 & 1.2 & 0.006 & 0.004 \\
\hline \multicolumn{9}{|c|}{ Gender } \\
\hline Girls & 65.4 & 49.1 & 5819410 & 0.336 & 0.204 & 39.7 & 0.238 & 0.142 \\
\hline Boys & 65.6 & 50.9 & 5985265 & 0.332 & 0.206 & 49.9 & 0.184 & 0.109 \\
\hline \multicolumn{9}{|c|}{ Urban/Rural location } \\
\hline Rural & 82.8 & 63.3 & 7376451 & 0.446 & 0.280 & 69.0 & 0.344 & 0.209 \\
\hline Urban & 48.6 & 36.7 & 4442491 & 0.226 & 0.133 & 31.7 & 0.139 & 0.080 \\
\hline \multicolumn{9}{|c|}{ Province } \\
\hline Western Cape & 37.9 & 5.0 & 587580 & 0.153 & 0.085 & 25.1 & 0.094 & 0.048 \\
\hline Eastern Cape & 77.9 & 20.1 & 2378696 & 0.415 & 0.258 & 59.8 & 0.292 & 0.174 \\
\hline Northern Cape & 69.1 & 2.0 & 235269 & 0.333 & 0.195 & 48.5 & 0.219 & 0.126 \\
\hline
\end{tabular}

\footnotetext{
${ }^{6}$ The headcount ratio, PO, is the number of poor below the poverty line out of the total population.

${ }^{7}$ The poverty gap is defined as the average poverty gap in a population as a proportion of a poverty line. It accounts for the intensity of poverty, meaning how poor the poor are.

${ }^{8}$ The severity of poverty gives more weight to the lowest incomes.
} 


\begin{tabular}{|l|c|c|r|c|c|c|c|c|}
\hline Free State & 63.6 & 5.9 & 695166 & 0.294 & 0.171 & 44.2 & 0.193 & 0.110 \\
\hline Kwazulu-Natal & 75.0 & 25.2 & 2975734 & 0.413 & 0.266 & 53.8 & 0.279 & 0.175 \\
\hline Northwest & 66.2 & 8.1 & 962355 & 0.345 & 0.216 & 49.3 & 0.239 & 0.143 \\
\hline Gauteng & 41.3 & 9.6 & 1138511 & 0.186 & 0.110 & 26.0 & 0.111 & 0.065 \\
\hline Mpumalanga & 66.4 & 7.2 & 846494 & 0.322 & 0.187 & 48.6 & 0.218 & 0.123 \\
\hline Limpopo & 78.0 & 16.9 & 2002739 & 0.400 & 0.242 & 65.6 & 0.313 & 0.183 \\
\hline
\end{tabular}

Source: Own calculations using income and expenditure of households (IES) 2005 data

Testing the robustness of the child poverty profile to select the poverty line found the age, race, gender, and urban-rural dimensions to be robust. In the poverty-relevant range, there is clear first order dominance in each of these cases. This implies that the poverty rankings are invariant to the poverty line chosen and to whether the poverty measure used is $\mathrm{P} 0, \mathrm{P} 1$ or $\mathrm{P} 2$. Figure 1 below shows that the results for the provincial rankings are slightly more complex and hence the provincial cumulative density functions or curves (CDFs) or poverty incidence curves. The CDF shows the population arranged from poorest to richest using the selected poverty measure and expresses those below any possible poverty line as a percentage of the total population (Deaton, 1997). In other words, it shows the headcount ratio of poverty at different poverty lines. It is therefore also known as a poverty incidence curve. Regardless of where the poverty line is drawn, Western Cape and Gauteng have the lowest child poverty headcount rates. However, the Western Cape has the lowest headcount up to an income level of approximately R6 000 per capita, per annum. Thereafter, however, there is a change. Except for the very low poverty lines, three provinces - Kwazulu-Natal, Limpopo and Eastern Cape - have the highest poverty headcounts. There is also a shift in the rankings of the weakest performers when alternative poverty lines are selected.

Figure 1: P0 (birth to 17 years) per province, per capita method

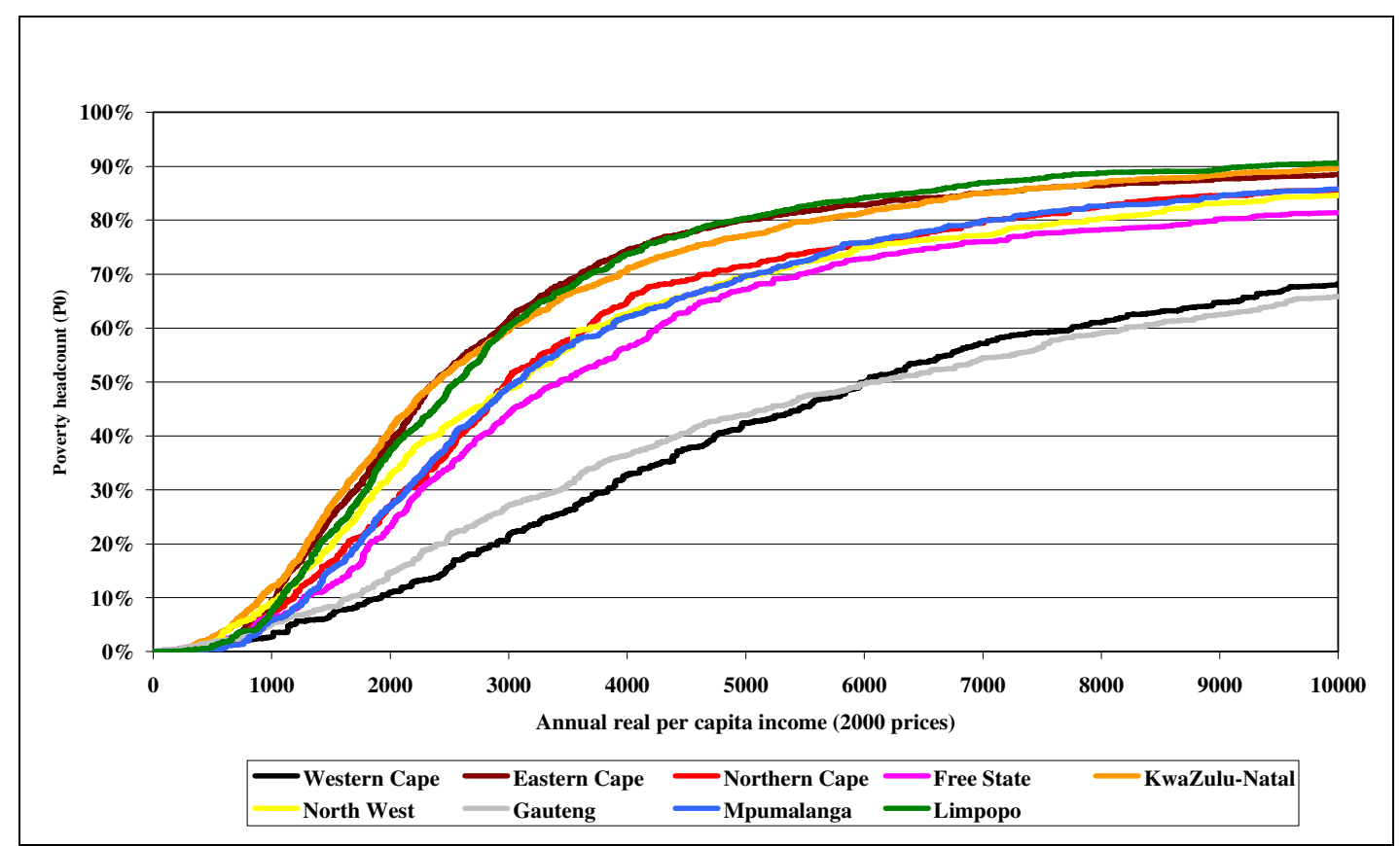

Where one CDF consistently lies above another, there is first-order stochastic poverty dominance. This implies that the ranking of poverty between two provinces remains unchanged whatever poverty line is used and whichever of the three FGT poverty measures (P0, P1 or P2) is analysed. The intersections of the lines implies that both 
the poverty line chosen and whether the poverty measure used is the headcount, depth or severity of child poverty affect the ranking of child poverty. This confirms the results from Table 2 . It does matter which measure is used, and this analysis implies that the choice of the poverty line itself is important for ranking poverty between provinces. At very low poverty lines, the severity of child poverty that Kwazulu-Natal experiences will be reflected even in the headcount index. However, if poverty lines are set high, there is a danger of underestimating Kwazulu-Natal's child poverty share when focusing on the headcount rate only.

The profile of child poverty in South Africa presented here, based on IES 2005, suggests that child poverty (at $65.5 \%$ ) remains more extensive than poverty amongst the population as a whole (52.9\%) and poverty amongst adults (45.2\%), if the chosen poverty line includes $40 \%$ of poor households. This confirms that children are found more often in poorer households. Moreover, despite the massive injection of transfers to households with poor children through child support grants, poverty amongst children remains substantial.

The child poverty profile sheds new light on the age dimensions of child poverty. The headcount, depth and severity of poverty are all higher amongst children in the youngest age cohort (birth to 4 ) followed by children aged 5 to 14 , followed by those aged 15 to 17 . This is surprising because the child support grant did not extend to the oldest group at the time of the survey. One would expect households containing only older children to experience more poverty.

\section{Methodology:}

To evaluate the impacts of the world economic crisis on South Africa, a sequential dynamic CGE model based on the dynamic Poverty and Economic Policy (PEP 1-t) standard model by Decaluwé et al (2009) was used, changing several assumptions to better reflect the South African economy. The model has two production factors, capital and labour. Labour is further disaggregated into informal, unskilled, semiskilled and highly skilled workers. The production function technology is assumed to be of constant returns to scale and is presented in a four-level production process. At the first level, output is a Leontief function of value added and total intermediate consumption. At the second level, a Constant Elasticity of Substitution (CES) function represents the imperfect substitution between composite labour and capital. At the third level, composite labour demand is also a CES function between composite skilled and composite unskilled labour. Note that the composite skilled 
demand is a CES with a low elasticity between skilled and semi-skilled workers, reflecting the fact that it is difficult to substitute semi-skilled for skilled workers. We also use a CES to describe the composite unskilled labour demand between informal and unskilled workers.

South Africa faces high unemployment and has a highly unionised labour force that has substantial bargaining strength. As a result, wages and salaries are strongly rigid downwards. To take this rigidity into account, it is assumed that wages cannot decline below some minimum. Thus, if production decreases, producers will not be able to adjust through a reduction in wage levels, and will therefore have to retrench some workers.

As South Africa is a small country, world prices are assumed exogenous. However, South African exporters face a less than infinite foreign demand for exports. In order to increase their market share on the world market, exporters need to reduce their Free On Board (FOB) prices for exports. Factor supplies are fixed in the first period and then grow at the population rate for labour force and using an accumulation equation for capital (Jung and Thorbecke, 2001). Transfers between institutions and government consumption in volume are fixed at the base year and then grow at the population rate. The rest of the world's savings are modelled as a fixed proportion of GDP.

An innovation of our study is that we split the economy into four different groups of activities. Each group is defined by its degree of dependency/exposure to the global crisis and is assumed to be affected differently by the crisis. The four groups are defined as follows (see Table in the Appendix).

Unaffected sectors (Group 1): It is assumed that these sectors will face neither a reduction in foreign demand nor a reduction in international prices. Basically, this group 1 consists of gold, food and beverage commodities.

Weakly affected Sectors (Group 2): These sectors are not heavily dependent on foreign trade and not closely related to other sectors. Found here are agriculture, clothing and wood.

Mildly affected sectors (Group 3): Like the previous group, these sectors are not heavily dependent on foreign trade but are closely linked to other sectors. Such 
sectors will react to a reduction in consumption, investment expenditures or reduction in demand for intermediate goods. This group includes most transports products, trade and construction.

Strongly affected sectors (Group 4): These sectors are closely linked to international markets either on the export or the import side. Here we find fossil fuels, other mining, machinery and equipment.

Two scenarios are presented and are distinguished by the magnitude of the recession (severe or moderate) (see Table 3 and 4). The moderate scenario is consistent with the view that growth is beginning to pick up, albeit moderately, from the end of 2009 onwards. A severe scenario is also modelled that reflects a protracted slow global growth era and implies tight public budgets for some time to come. It is important to investigate what impact that scenario might have on the sustainability of interventions to protect children and poor families.

Table 3 : Moderate scenario

\begin{tabular}{|l|l|l|}
\hline & \multicolumn{1}{|c|}{$\begin{array}{c}\text { Changes in world prices of exports and } \\
\text { imports }\end{array}$} & Changes in world demand for exports \\
\hline Weakly affected & $-2 \%$ in 2008 and 2009 & \\
\hline Mildly Affected & $-3.5 \%$ in $2008-2009$ and $+2.1 \%$ in 2010 & $-2 \%$ in $2008-2009$, and $+2.1 \%$ in 2010 \\
\hline Strongly affected & $-5 \%$ in $2008-2009$ and $+2.1 \%$ in 2010 & $-2 \%$ in $2008-2009$, and $+2.1 \%$ in 2010 \\
\hline
\end{tabular}

Table 4: Severe Scenario:

\begin{tabular}{|l|l|l|}
\hline \multicolumn{1}{|c|}{ Sectors } & \multicolumn{1}{c|}{$\begin{array}{c}\text { Changes in world prices for exports and } \\
\text { imports }\end{array}$} & Changes in world demand for exports \\
\hline Weakly affected & $-10 \%$ in 2008 and 2009 & \\
\hline Mildly Affected & $-15 \%$ in 2008 and 2009 & $-10 \%$ in $2008-2009$, and $+1 \%$ in 2010 \\
\hline Strongly affected & $-20 \%$ in 2008 and 2009 & $-10 \%$ in $2008-2009$ \\
\hline
\end{tabular}

In terms of foreign financing of domestic firms, we assume that foreign transfers to firms decrease by $5 \%$ in $2008-2009$ and then increase by $2.1 \% 2010$ in the moderate scenario. In the severe scenario, we assume that they decrease by $10 \%$ in $2008-2009$ and then increases by $1 \%$ from 2009 to 2010 . This reduction corresponds to a tightening of the liquidity available to firms to finance their investment program and has an indirect impact on investment (through a decrease in savings from firms) and on the current account, as it reduces the financial resources available to finance imports and will require an increase in exports to compensate. After 2010, world 
prices recover to their BAU values and world demand increases at the population growth rate.

The economy-wide model just described was used together with a micro model of the economy, to estimate the likely effect of the economic crisis on child poverty in South Africa. Essentially, the major purpose of the micro model was to estimate the effect of the economic changes simulated by the CGE model on households through three channels:

1. Variations in prices, which were assumed to apply to all households. Differences only arose in their spending habits. Note that adult equivalence scales were also applied to allow for differential spending patterns.

2. Variations in wages in different skill categories.

3. Changes in employment for the three formal labour market categories.

The methodological approach draws from the work of Cockburn et al. (forthcoming UNICEF and PEP working paper), Bibi et al. (forthcoming UNICEF and PEP working paper and 2009). The micro analysis distinguishes 14 food and 1 non-food group. Aggregate household consumption was converted to per capita equivalents using a "caloric requirements" approach based on WHO calorie requirements tables by age and sex (FAO/WHO/UNU 1985). The Almost Ideal Demand Systems (AIDS) approach of Deaton and Muellbauer (1980) was used for converting individual consumption into real consumption and comparing it over time. The share of each good category in terms of total household consumption and the district median unit price for all food categories were required for estimating the parameters of the demand system. The AIDS model was estimated following Deaton (1997) and relies 
on the spatial variability of prices within a country in order to estimate the parameters. A three-stage least squares model was used for this purpose. The poverty rate before the crisis was calculated by dividing real consumption by the poverty line for the reference area, resulting in a new poverty line for all individuals (Bibi et al, 2009: 74). To calculate poverty rates after the crisis, individual consumption in real terms was re-estimated after replacing the price vector with the new vector of prices (obtained from the macro model) and the change in total household income. Price and wage variations are relatively small and have little effect on poverty in the model. Changes in employment had easily the greatest effect on poverty. Probit models of the probability of employment for each employed and unemployed worker for jobs in various skills categories were estimated. These models were then used to identify those employed workers in each skill category most likely to lose their jobs when employment declines relative to the labour force. The wages of employed workers were assumed to remain as they had been recorded. The dataset used for the micro simulations was the 2008 National Income Dynamics Survey (NIDS). The 2008 data was assumed to reflect the situation before the 2007 crisis. The model was then applied to these data to arrive at simulations. Because the micro simulations dealt essentially with a static model, no projections beyond 2011 were attempted. Poverty would almost have returned to its usual level, in terms of both scenarios, by then.

\section{Results}

Given the magnitude of the different shocks, each scenario will generate differential outcomes on output, the entire price structure and, consequently, factor reallocation. However, the final impact on households will depend on their factor endowments and their sources of income, including transfers, as well as their consumption patterns. 
The results of the CGE analysis are discussed first and then followed by the results of the micro modelling.

\section{Results from the CGE model}

The CGE model assumes that in order to gain foreign market share, South African exporters must reduce their FOB prices, taking into account prices of competitors and the world elasticity of demand for South African goods. Table 5 summarises the impact of the two scenarios on South African FOB prices. As can be seen, there is a huge decrease in exports prices following the drop in international prices and demand. The decrease is of course much greater for the severe scenario. For the strongly affected sectors the drop of these prices is a little less than the drop in world export prices $(-5 \%$ in 2008 and 2009 for world prices and $-4 \%$ and $-2.7 \%$ for the FOB prices in the moderate scenario). This implies that South African firms are losing ground with respect to their competitors and do not adjust fully to the new conditions, the downward rigidity of the wage rate limiting the adjustment capacity of the firms. The same is true for the severe scenario. It will be shown later that in terms of volume of exports, the drop of South African exports is greater than the reduction in the world demand. Note also that for non-affected sectors, the decrease in FOB prices is essentially due to the decrease in the cost of trade and transportation margins. In the two scenarios, world prices of exports increase by $2.1 \%$ in 2010 and resume their BAU level for the following years (up to 2015). This positive trajectory of world export prices nearly eliminates the effect of the preceding drop, but even in the long run, FOB prices remain below their BAU level.

Table 5: Impact on export prices (\% change from BAU)

\begin{tabular}{|l|r|r|r|r|r|r|r|r|r|}
\hline & & \multicolumn{4}{|c|}{ Moderate } & \multicolumn{4}{|c|}{ Severe } \\
\hline Commodities & Initial & 2008 & 2009 & 2010 & 2015 & 2008 & 2009 & 2010 & 2015 \\
\hline
\end{tabular}




\begin{tabular}{|l|r|r|r|r|r|r|r|r|r|}
\hline & $\begin{array}{r}\text { export } \\
\text { shares }\end{array}$ & & & & & & & & \\
\hline Non-affected & 11.0 & -0.9 & -0.9 & -0.4 & -0.3 & -3.2 & -3.7 & -1.4 & -1.6 \\
\hline Weakly affected & 9.0 & -1.9 & -1.7 & -0.2 & -0.1 & -8.5 & -8.7 & -0.7 & -0.5 \\
\hline Mildly affected & 31.8 & -3.3 & -2.1 & -0.5 & -0.3 & -14.0 & -13.9 & -2.2 & -2.1 \\
\hline Strongly affected & 48.2 & -4.0 & -2.7 & -0.3 & -0.3 & -16.6 & -16.3 & -1.6 & -1.8 \\
\hline All & 100.0 & -3.3 & -2.2 & -0.4 & -0.3 & -13.6 & -13.5 & -1.7 & -1.7 \\
\hline
\end{tabular}

The drop of world prices of imports will reduce the domestic cost of imported goods even if the reduction is, in percentage points, a little less than the reduction in world price. For the moderate scenario, in 2008 , we observe that import prices drop more than local prices for strongly and mildly affected sectors. As expected, these sectors experience a relative increase in imports compared to domestic purchases. The opposite pattern is observed for the weakly affected or non-affected sectors. It is important to note for the latter that there is a decrease in import prices due to margins. As expected, results reported in Table 6 show that exports decrease strongly for products belonging to the strongly affected sectors, and deeper in the severe scenario. In 2008 , at the beginning of the crisis, exports decrease by $21.5 \%$ for strongly affected sectors under the severe scenario. The drop in world demand has a direct effect on exports and the lower reduction in FOB prices with respect to world prices also reduces the performance of exports.

It is important here to understand the behaviour of the non-affected sectors. Globally speaking, they benefit from the difference between local prices (that are sharply decreasing) and export prices (that are hardly affected)). The real exchange rate depreciates strongly and this movement favours only those exporting sectors that are not affected by the reduction in foreign demand and international prices. For instance, the gold sector, a non-affected sector, sees its volume of exports increasing by $3.1 \%$ in 2008 in the moderate scenario and by $10.6 \%$ in the severe scenario.

Table 6: Impact on exports (\% change from BAU)

\begin{tabular}{|l|r|r|r|r|r|r|r|r|r|}
\cline { 2 - 8 } \multicolumn{2}{c|}{} & \multicolumn{4}{c|}{ Moderate } & \multicolumn{4}{c|}{ Severe } \\
\hline Commodities & $\begin{array}{r}\text { Initial } \\
\text { exports }\end{array}$ & 2008 & 2009 & 2010 & 2015 & 2008 & 2009 & 2010 & 2015 \\
\hline
\end{tabular}




\begin{tabular}{|l|r|r|r|r|r|r|r|r|r|}
\hline & shares & & & & & & & & \\
\hline Non-affected & 11.0 & 3.3 & 3.2 & 1.3 & 0.9 & 12.4 & 13.8 & 4.7 & 5.4 \\
\hline Weakly & 9.0 & -0.0 & -0.6 & 0.8 & 0.3 & -3.8 & -3.2 & 3.3 & 2.2 \\
\hline Mildly & 31.8 & -2.6 & -1.1 & -0.5 & -0.9 & -13.3 & -14.6 & -4.6 & -5.0 \\
\hline Strongly & 48.2 & -5.2 & -3.9 & -0.9 & -1.1 & -21.5 & -23.0 & -7.0 & -6.8 \\
\hline All & 100.0 & -3.0 & -1.9 & -0.4 & -0.7 & -13.6 & -14.5 & -4.0 & -4.1 \\
\hline
\end{tabular}

A sharp decrease is also noted on the import side. As will be shown later, total income of households will drop substantially, leading to a huge reduction in total absorption and a reduction of demand for imported goods. In the moderate scenario this demand reduction is sufficient to compensate for the positive expansion effect of lower import prices. Altogether, imports fall by $2.1 \%$ in the strongly and mildly affected sectors. However this decrease will be greater for non-affected and weakly affected sectors as the local price falls more than the import price. One should also keep in mind the constraint set on the current account balance, which is assumed to remain fixed relative to GDP. This assumption implies that if the country's exports decrease, then its imports would have to follow the same path.

As explained previously, the contraction on the demand side translates into fewer imports. This will affect domestic demand even more dramatically due to the increased competitiveness of foreign products created by the reduction in import prices. The decrease in the total demand for goods will have consequences for sectoral production. One would actually expect production to decrease most strongly for sectors strongly dependent on exports. On the other hand, sectors that are not directly affected by the crisis might be affected by a reduction of demand from other sectors, for instance in terms of intermediate consumption. Finally, all the groups are affected by the crisis and see their production decrease. The decrease in the production of most of the sectors will have a number of consequences.

Firms that see their exports and production fall will retrench workers as they are unable to adjust the nominal wage of labour. As unions are strong, producers will not 
be able to decrease wage rates to adjust to the fall in prices and demand, so they will have to dismiss more workers. Only non-affected sectors, and notably the gold sector, benefit from the crisis. We saw earlier that gold production was increasing, and this is leads to job creation in this sector. The process of retrenchments will not be uniform across the different labour categories (Table 7). Highly skilled workers are the ones who suffer the least from the crisis. Although there are important job losses during 2008 and 2009 (and 2010 for the severe scenario), the economy rapidly faces a shortage of skilled workers. This situation represents particularly well what happened during this period in South Africa.

Table 7: Impact on total labour demand (\% change from BAU)

\begin{tabular}{|l|c|c|c|c|c|c|}
\cline { 2 - 7 } \multicolumn{1}{c|}{} & \multicolumn{2}{c|}{ High Skilled } & \multicolumn{2}{c|}{ Skilled and Semi-Skilled } & \multicolumn{2}{c|}{ Low skilled } \\
\hline \multicolumn{1}{c|}{ YEARS } & MOD & SEV & MOD & SEV & MOD & SEV \\
\hline 2008 & -4.40 & -20.73 & -4.90 & -19.57 & -5.86 & -23.87 \\
\hline 2009 & -2.36 & -20.82 & -3.96 & -20.50 & -4.23 & -24.65 \\
\hline 2010 & 0 & -5.49 & -1.33 & -7.86 & -1.04 & -8.24 \\
\hline 2015 & 0 & 0 & -1.21 & -6.59 & -0.99 & -5.28 \\
\hline
\end{tabular}

In the BAU, for each labour category, we observe that unemployment is decreasing through time due to the fact that capital grows faster than labour. Results reported in Table 8 show that for highly skilled workers only, in the base year, the unemployment rate is very low (1\%) and actually decreases in the BAU to reach $0 \%$ in 2007 . In 2009 , in the severe scenario, for skilled workers, their unemployment rate reaches a little more than $20 \%$.

Table 8: Unemployment rate (\%)

\begin{tabular}{|l|c|c|c|c|c|c|}
\cline { 2 - 7 } \multicolumn{1}{c|}{} & \multicolumn{2}{c|}{ High Skilled } & \multicolumn{2}{c|}{ Skilled and Semi-Skilled } & \multicolumn{2}{c|}{ Low skilled } \\
\hline YEARS & MOD & SEV & MOD & SEV & MOD & SEV \\
\hline 2005 & 1.00 & 1.00 & 15.00 & 15 & 26.4 & 26.4 \\
\hline 2008 & 4.40 & 20.73 & 17.18 & 29.96 & 28.16 & 41.90 \\
\hline 2009 & 2.36 & 20.82 & 15.50 & 30.05 & 26.07 & 41.83 \\
\hline 2010 & 0.0 & 5.49 & 12.23 & 18.04 & 22.73 & 28.36 \\
\hline 2015 & 0.0 & 0.0 & 7.02 & 12.08 & 18.42 & 21.96 \\
\hline
\end{tabular}


Recall that there are actually four types of labour in the model, the three described above and informal labour. Assuming no unemployment of informal labour, the impact of the crisis for this type of labour will be on their wage rate, which falls sharply (-5\% in 2008 in the moderate, and $-22 \%$ for the severe scenario). In the same way, it is not surprising to see a decrease in the rate of return of capital in most sectors, as most of them are affected by the crisis either through a drop in selling prices or demand. Taking these results into account, we can now analyse what happens to the different agents following the crisis.

The sharply decreasing rate of return to capital leads to strong negative effects on firm income as this component represents $88 \%$ of their total income. Moreover, one of the channels through which the crisis operates is modelled as a decrease in transfers from abroad. Thus, we expect firms' income to decrease even more. Firm income decreases by $16 \%$ in 2008 in the severe scenario, and even in the long run it cannot return to its BAU level.

Firm savings are obtained after removing from their income the amount of direct taxes paid to the government as well as transfers to other institutions (mainly households and the rest of the world). We expect a dramatic fall in firm saving which is more pronounced in the short run. This decrease in firm savings will have important consequences for total investment. Indeed, firm savings represent $80.5 \%$ of total investment. Here again, we can see that, even in the moderate scenario, the effect of the crisis remains in the long run as firm savings remains below its BAU level ($1.5 \%)$.

Households receive income from labour and transfers from firms, government and the rest of the world. We assume that transfers from government and the rest of the world are fixed, whereas transfers from firms are a proportion of firm income. As household 
income is mainly based on labour income, we expect it to decrease. Moreover, as mentioned previously, firm income is decreasing and so are the dividends it pays. Thus, household income decreases sharply in both scenarios. This decrease negatively affects household consumption and savings and thus total absorption through a reduction in consumption and investment.

Government revenue is expected to decrease. Indeed, direct taxes are decreasing (as a share of households and firm income), and taxes on products are also decreasing for most sectors (due to the decreases in imports and production). Half of government income comes from direct taxes and around a third from indirect taxes on products. The drop in these two components will contribute to a total decrease in government revenue and a substantial increase in its deficit.

In both scenarios made about the severity of the crisis, GDP falls in 2008 and 2009 and then increases again. However, it does not return to its BAU value even by 2015 . In other words, without positive shocks or deliberate and successful interventions to stimulate the economy and counteract the negative effect of the world crisis, GDP will not recover to what it would have been without the crisis. Given all the preceding effects, it is no surprise to observe a huge decrease in total investment. What is relevant here is that, even though the crisis affected only 2008 and 2009 and the recovery started in 2010, the effects on investment remain in the long term. Both scenarios predict lower investment in 2015 than the BAU does 9 .

\footnotetext{
${ }^{9}$ On the other hand we could argue that, in the long run, the reduction in investment will lead to a reduction in the capital stock because of the continuous depreciation of capital stock. A reduction in the speed that capital is accumulated could eventually lead to a change in the rate of return of capital. This could cause firms and households to increase their savings. The same argument could apply to the behaviour of foreign firms. They could eventually rebuild their capital stock, thereby helping their domestic partners to increase their investments. If this happens, then the permanent effects mentioned here of the crisis could eventually become only temporary if the households and firms try to rebuild their stock of capital at their usual levels.
} 


\section{Results from the micro-model}

Child poverty in 2007 (before the crisis) was estimated at $52.6 \%$ when using the moderately low poverty line of R250 per capita per month in 2000 rand terms, or R377 in January 2008 (when applying the NIDS data) ${ }^{10}$. Without an economic crisis, this headcount rate of child poverty would be declining by a small percentage every year if one linked the macro and the micro simulations. It would have declined to $52.2 \%$ in 2008 and to $51.9 \%$ in 2009 . It would have declined to $51.8 \%$ by 2011 according to the business as usual simulations. Thus, business as usual would have meant a slow but continuing decline in child poverty.

Table 9: Trends in poverty under three scenarios, 2007-2011

\begin{tabular}{|c|c|c|c|c|c|c|c|c|}
\hline & & & BAU & $\begin{array}{c}\% \\
\text { change } \\
\text { (relative } \\
\text { to } \\
2007 \text { ) } \\
\end{array}$ & $\begin{array}{c}\text { Moderate } \\
\text { scenario }\end{array}$ & $\begin{array}{c}\% \\
\text { change } \\
\text { (relative } \\
\text { to } \\
2007 \text { ) } \\
\end{array}$ & $\begin{array}{c}\text { Severe } \\
\text { scenario }\end{array}$ & $\begin{array}{c}\% \\
\text { change } \\
\text { (relative } \\
\text { to } \\
2007 \text { ) } \\
\end{array}$ \\
\hline \multirow[t]{6}{*}{2007} & Individual level & P0 & 0.468 & $0.0 \%$ & & & & \\
\hline & & P1 & 0.183 & $0.0 \%$ & & & & \\
\hline & & $\mathrm{P} 2$ & 0.095 & $0.0 \%$ & & & & \\
\hline & Child level & PO & 0.526 & $0.0 \%$ & & & & \\
\hline & & P1 & 0.205 & $0.0 \%$ & & & & \\
\hline & & $\mathrm{P} 2$ & 0.107 & $0.0 \%$ & & & & \\
\hline \multirow[t]{6}{*}{2008} & Individual level & PO & 0.463 & $-1.1 \%$ & 0.471 & $0.6 \%$ & 0.508 & $8.5 \%$ \\
\hline & & $\mathrm{P} 1$ & 0.182 & $-0.5 \%$ & 0.208 & $13.7 \%$ & 0.287 & $56.8 \%$ \\
\hline & & $\mathrm{P} 2$ & 0.095 & $0.0 \%$ & 0.125 & $31.6 \%$ & 0.212 & $123.2 \%$ \\
\hline & Child level & PO & 0.522 & $-0.8 \%$ & 0.527 & $0.2 \%$ & 0.549 & $4.4 \%$ \\
\hline & & P1 & 0.205 & $0.0 \%$ & 0.230 & $12.2 \%$ & 0.294 & $43.4 \%$ \\
\hline & & $\mathrm{P} 2$ & 0.106 & $-0.9 \%$ & 0.137 & $28.0 \%$ & 0.208 & $94.4 \%$ \\
\hline \multirow[t]{6}{*}{2009} & Individual level & P0 & 0.462 & $-1.3 \%$ & 0.465 & $-0.6 \%$ & 0.510 & $9.0 \%$ \\
\hline & & P1 & 0.182 & $-0.5 \%$ & 0.197 & $7.7 \%$ & 0.287 & $56.8 \%$ \\
\hline & & $\mathrm{P} 2$ & 0.095 & $0.0 \%$ & 0.113 & $18.9 \%$ & 0.212 & $123.2 \%$ \\
\hline & Child level & PO & 0.519 & $-1.3 \%$ & 0.522 & $-0.8 \%$ & 0.545 & $3.6 \%$ \\
\hline & & P1 & 0.204 & $-0.5 \%$ & 0.219 & $6.8 \%$ & 0.304 & $48.3 \%$ \\
\hline & & $\mathrm{P} 2$ & 0.106 & $-0.9 \%$ & 0.125 & $16.8 \%$ & 0.215 & $100.9 \%$ \\
\hline 2010 & Individual level & PO & 0.462 & $-1.3 \%$ & 0.460 & $-1.7 \%$ & 0.479 & $2.4 \%$ \\
\hline
\end{tabular}

\footnotetext{
${ }^{10}$ This is a poverty line often quoted in the literature. The 'lower bound' poverty line of Statistics South Africa of R322, quoted by Woolard and Leibbrandt (2006) and derived by Hoogeveen and Ozler (2005), is about 30\% higher. The 'upper bound' line of R593 per capita per month in 2000 is about $140 \%$ higher.
} 


\begin{tabular}{|l|l|l|l|l|l|l|l|l|}
\hline & & P1 & 0.181 & $-1.1 \%$ & 0.181 & $-1.1 \%$ & 0.216 & $18.0 \%$ \\
\hline & & P2 & 0.094 & $-1.1 \%$ & 0.094 & $-1.1 \%$ & 0.133 & $40.0 \%$ \\
\hline & Child level & P0 & 0.519 & $-1.3 \%$ & 0.518 & $-1.5 \%$ & 0.536 & $1.9 \%$ \\
\hline & & P1 & 0.203 & $-1.0 \%$ & 0.203 & $-1.0 \%$ & 0.238 & $16.1 \%$ \\
\hline $\mathbf{2 0 1 1}$ & Individual level & P2 & 0.105 & $-1.9 \%$ & 0.105 & $-1.9 \%$ & 0.145 & $35.5 \%$ \\
\hline & & P0 & 0.459 & $-1.9 \%$ & 0.460 & $-1.7 \%$ & 0.472 & $0.9 \%$ \\
\hline & & P1 & 0.179 & $-2.2 \%$ & 0.180 & $-1.6 \%$ & 0.206 & $12.6 \%$ \\
\hline & Child level & P2 & 0.093 & $-2.1 \%$ & 0.094 & $-1.1 \%$ & 0.122 & $28.4 \%$ \\
\hline & & P0 & 0.518 & $-1.5 \%$ & 0.518 & $-1.5 \%$ & 0.529 & $0.6 \%$ \\
\hline & & P1 & 0.201 & $-2.0 \%$ & 0.202 & $-1.5 \%$ & 0.228 & $11.2 \%$ \\
\hline
\end{tabular}

Note: \% change is shown relative to BAU in 2007

Source: Own projections

Figure 4 shows that the most severe effects of the crisis occurred in 2008 and 2009,

while by 2010 the effects on poverty were already being reversed to some extent,

even under a severe scenario. Its scale allows for a visual inspection of the different

effects, but the range is small. However, it accentuates the stark difference between

the severe and moderate scenarios.

Figure 2: The poverty headcount ratio (P0) for 2007 to 2011 under three scenarios: Business as Usual, Moderate Scenario and Severe Scenario

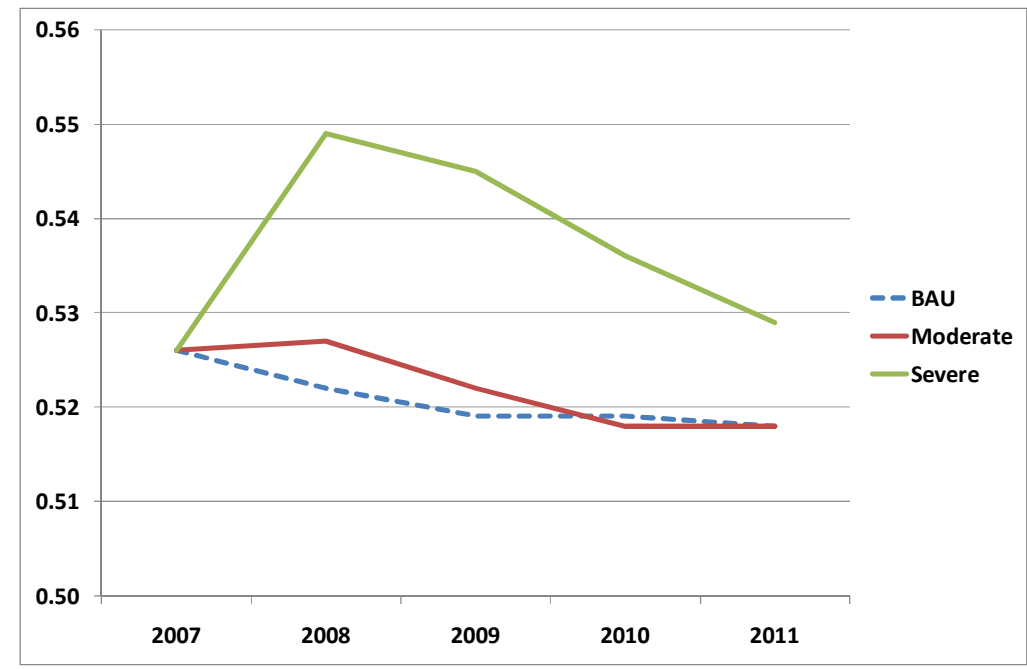

If one focuses on the headcount ratio only, and uses this slightly below conventional poverty line, it is clear that the effect of the moderate scenario on the child poverty 
headcount was quite small in $2008^{11}$. The child poverty headcount ratio (P0) hardly increases (by only 0.1 percentage points, or $0.2 \%$ ). However, there is a $12 \%$ increase in the child poverty gap ratio (P1) and a $28 \%$ increase in the child poverty severity ratio (P2). This indicates that many of the changes in the economic situation in 2008, in terms of the moderate scenario, occur at lower levels of income (that is, some way below the poverty line). Thus, the poorest are also the most affected. The moderate scenario shows that child poverty actually starts improving in 2009 . The headcount ratio drops to $52.2 \%$, only $0.3 \%$ above the level of poverty that would have applied in the business as usual scenario and below the initial poverty headcount ratio.

Nevertheless, some effect on the poverty gap ratio and on the poverty severity ratio for children remains. This indicates that, although fewer children were poor in 2007 , the changes at the bottom of the distribution have worsened the situation for the worst off children. If the poverty line had been drawn at a lower level, the poverty headcount also would have risen.

In the case of the more severe economic growth scenario, the child poverty headcount ratio would rise by $4.4 \%$ (2.3 percentage points) to $54.9 \%$ in 2008 compared to 2007 , the poverty gap ratio by $43 \%$ and the poverty severity ratio by $94 \%$. This again illustrates the severe consequences for children at the bottom of the income distribution, that is, far below conventionally used poverty lines. Clearly, in the severe economic scenario, very poor children were greatly affected by the crisis in 2008 . There was little further change in the poverty figures in 2009 if one used the three conventional measures.

\footnotetext{
${ }^{11}$ In practice, poverty lines for this model are derived for each cluster of households in the sample using price levels in their area as reflected by consumption patterns. The per capita lines are those derived directly from the data without considering prices by determining what poverty line would give the same child poverty headcount ratio.
} 
Figure 3 shows the effect of the moderate scenario in 2008 and 2009 against the initial situation in terms of cumulative density functions. If one CDF line lies clearly above poverty, using any of the conventional measures and irrespective of the poverty line chosen, we have stochastic poverty dominance. The three lines showing the initial situation and the moderate scenarios in 2008 and 2009 are barely distinguishable, except at the very lowest income levels, where there is clear poverty dominance. These scenarios show relatively small changes that would probably fall within $95 \%$ confidence levels of the initial cumulative density function. In comparison, the child poverty situation would have been much worse if there had been no child support grant: the line depicting that situation lies well above all the other three lines. Thus, the moderate scenario for the economic crisis shows an effect that is far too small to undo the beneficial effects for children of the earlier introduction and expansion of the child support grant.

Figure 3: Cumulative density functions (curves) for child poverty in 2007, 2008 and 2009, in the moderate scenario, and a comparison with the beneficial effects of the child support grant 


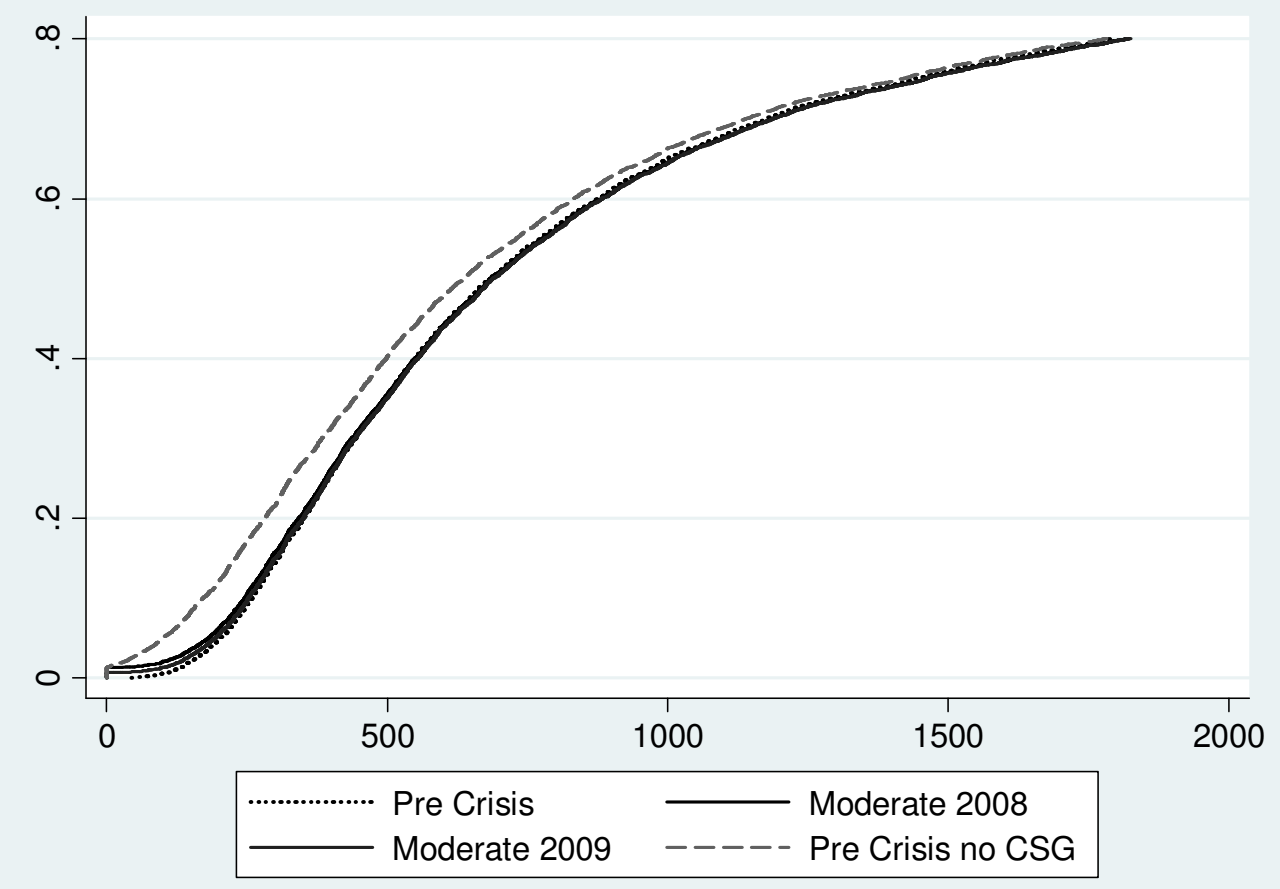

Figure 4 shows the CDFs that compare the 2007 situation with the effect of the severe scenario in 2008 and 2009. Here the effect of the crisis is much clearer and there appears to be complete poverty dominance. Irrespective of the poverty measure or poverty line chosen, except for very high poverty lines, there is a large (and probably statistically significant) effect on poverty. It is even larger among the very poor and offsets the beneficial effects of the child support grant.

Figure 4: Cumulative density functions (curves) for child poverty in 2007, 2008 and 2009, in the severe scenario, and a comparison with the beneficial effects of the child support grant 


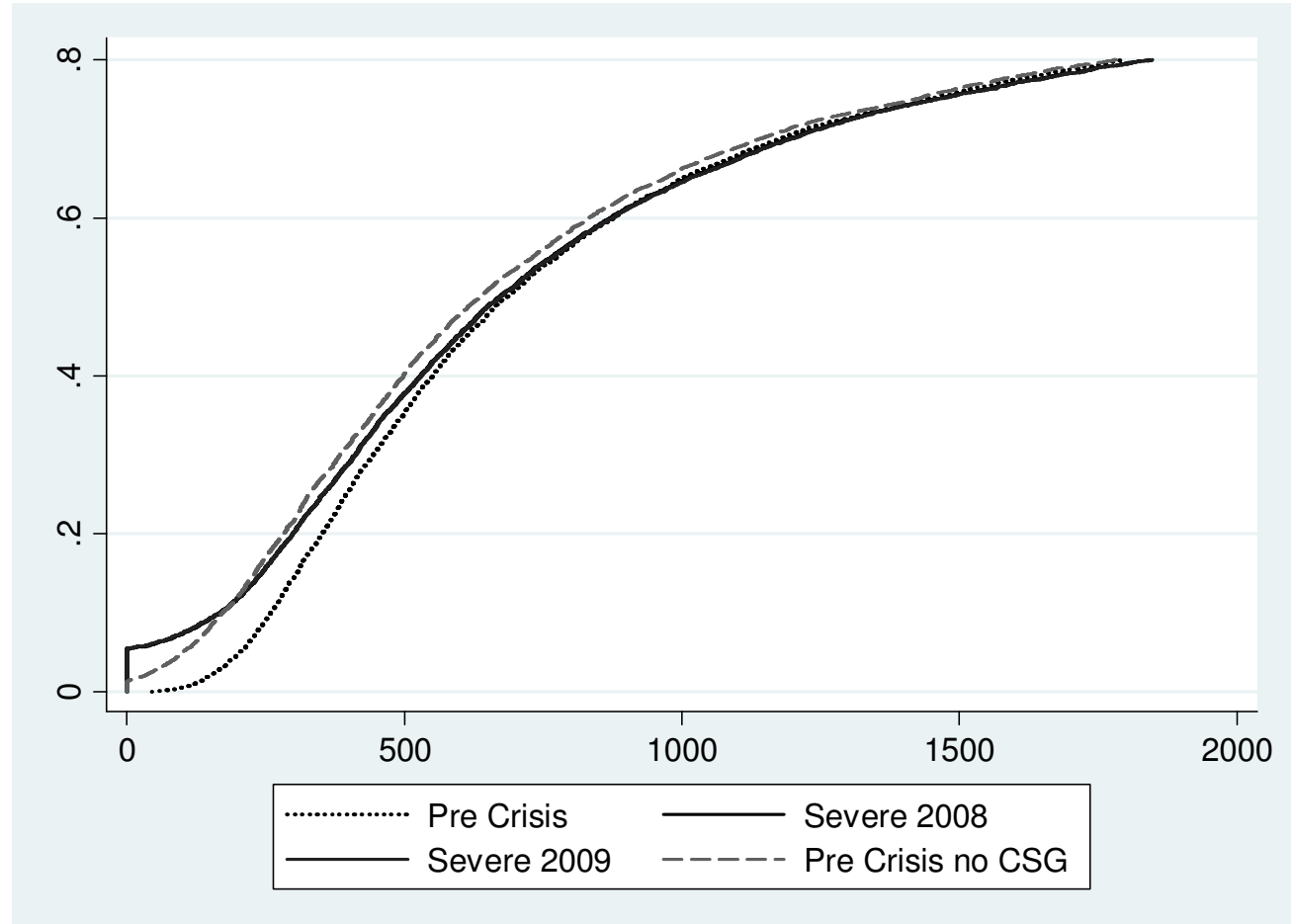

In summary, the cumulative density functions indicate that the effect of the moderate scenario is not that large. In contrast, the effect of the severe scenario is great, particularly at the lower levels. Clearly, we are dealing with poverty effects that affect the poorest most.

Using a lower poverty line confirms what the CDFs and the magnitude of the effects on $\mathrm{P} 1$ and $\mathrm{P} 2$, relative to $\mathrm{P} 0$, have already intimated. This is that the major effect of the crisis is closer to the bottom of the income distribution. At the lower line, the effect of the severe scenario is to increase the poverty headcount ratio more than was the case at the higher line.

Another way of looking at this is to separate the effects on child poverty in urban and rural areas. Poverty amongst children is more severe in rural than in urban areas. In 2007 , before the crisis, poverty amongst children in urban areas was $44.9 \%$ as against $58.7 \%$ in rural areas. The economic crisis appears to have a similar effect in terms of 
who crosses the poverty line in urban and in rural areas, as the rise in P0 is quite similar in magnitude. However, the crisis affects already poor children in rural areas much more. $\mathrm{P} 2$ rises by $55 \%$ in urban areas in 2009 and by $136 \%$ in rural areas, using the severe scenario. All poverty measures improve a little in urban areas, while P2 deteriorates by $31 \%$ in rural areas if one applies the moderate scenario. Even the price effects, which tend to moderate the difference at lower incomes, cannot overcome the greater effect of labour market events in rural areas. This clearly needs a longer run to determine the positive effect of a return to economic growth.

The greater effect of the crisis at lower income levels and in rural areas may, at first glance, appear strange. However, further investigation shows that, although much of the income loss occurs in urban areas and even among skilled workers, these people are better protected against job losses because they are often members of households that have a variety of other income sources. Apart from social grants, which have a similar effect of diversifying income among the poor, the poor and rural dwellers are, in many cases, quite weakly protected against job loss. It is therefore not surprising that they fall below, or further below, the poverty line when they lose their jobs.

If one separates that part of the effect caused by price changes and job losses, we see that the effect of job losses is by far the greater. Nevertheless, price changes do play an independent role and in some situations serve to moderate the effect of poverty on rural compared to urban areas. This particularly applies to people close to the poverty line. $^{12}$

\section{Conclusion}

\footnotetext{
${ }^{12}$ This may not seem an appropriate way of modelling the results, and one may wish to revert to a scenario in which only the effect of the labour market is measured. Nevertheless, in this model, poverty lines have been set for each cluster of observations in the initial sample based on the price ratios that appear to apply in those clusters. The methodology is described in the technical report.
} 
Child poverty is high and has already long been a source of concern in South Africa, thus the progress made in the past decade to reduce it through expanding the child grant system was very important. This paper has shown that a decrease in world prices, together with the drop in world demand, led to a fall in production for most sectors. This reduces employment and unemployment rates increase as a result. Households see their income drop. The situation is worse for informal workers who do not have the protection of an effective wage floor that unions provide. They face a huge drop in their wage rate (earnings). Firms also suffer from the crisis as their incomes and savings decrease tremendously. Even if the crisis only lasts for 2008 and 2009, its effects will remain long afterward, particularly because of the permanent effect of the drop in investment. The combination of macro- and micro-modelling in this paper shows that the impact of the economic crisis did not completely reverse the positive impact of the grants. Yet it is evident that the economic crisis did indeed have an impact on monetary poverty in South Africa. The moderate scenario shows a limited impact, but it is felt most by the poorest. In the case of the severe scenario, the impact is much greater and it affects the poorest again by far the most. The Child Support Grant provides some protection against the effects of the economic crisis. How likely are the two scenarios discussed? One should consider that the CGE model specifically attempted to isolate the effects of the global financial crisis, separate from the earlier but perhaps enduring effects of the international fuel and food crises. Thus actual outcomes may be worse than modelled. It appears, from present knowledge, as if the moderate scenario may better reflect the course of the international economy than the severe scenario. Further, it appears as if the economic impact of the crisis has been less than under the severe scenario, yet the employment effects appear considerably worse than the moderate scenario. This may be the result of even greater 
wage rigidities (increasing wages during an economic crisis) than allowed for in the macro-model.

The time period over which this paper has looked at the crisis did not really allow for a policy response in terms of anti-poverty policy. In fact, such responses are always slow to implement and depend largely on existing institutions. The Child Support Grant in South Africa is a major instrument to this end, as it is already in place and protects the vulnerable both before the crisis and during it. Moreover, in principle it is possible to use it to expand transfers to households, though the constellation of fiscal forces in South Africa (the fact that grants are already being expanded very rapidly) and the relatively short duration of this crisis reduced its potential role during this crisis.

It needs to be emphasised that this paper did not consider household and individual responses to poverty, which may have unknown impacts on actual poverty outcomes, particularly for children, who cannot protect themselves from the impact. Intrahousehold behaviour, for instance the extent to which households allocate their resources to protect children from the worst effects of the crisis, is of particular importance. But household formation, dissolution and fracturing can all occur in response to changing economic situations. To some extent, the Child Support Grant mitigates the possible impact of such behaviour on children, as it makes it more attractive to have them as part of the household. 


\section{References}

Annabi, N; Decaluwé, B; and Cockburn, J. (2006), "Functional forms and parameterization of CGE models", PEP, MPIA Working Paper 2006-04.

Behar, A.; and Edwards, L. (2004), "Estimating elasticities of demand and supply for South African manufactured exports using a vector error correction model", The Centre for the Study of African Economies, Working Paper 204

Deaton, A. (1997), The analysis of household surveys: Microeconomic analysis for development policy. Washington DC: World Bank.

Deaton, A. \& Muellbauer, J. (1980), Economics and Consumer Behaviour, Cambridge University Press, Cambridge, UK (1980).

Deaton, A., \& Muellbauer, J. (1986), On Measuring Child Costs: With Applications to Poor Countries. Journal of Political Economy, vol.94, no.4:720-744.

Decaluwé, B, Lemelin,A, Maisonnave, H and V Robichaud (2009), PEP-1-t. Standard PEP model: single-country, recursive dynamic version, Poverty and Economic Policy Network, Université Laval, Québec.

FAO/WHO/UNU. (1985), Energy and protein requirements. In: WHO Technical Report Series No. 724. World Health Organization, Geneva.

Foster, J., Greer, J. \& Thorbecke, E. (1984), A class of decomposable poverty measures. Econometrica, Vol. 52(3): pp. 761-766.

Gibson, K.L. (2003), Armington Elasticities for South Africa: Long- and Short-Run Industry Level Estimates, Trade and Industrial Policy Strategies, Working Paper 12-2003

Hoogeveen, J.G. and Özler, B (2005). Not Separate, Not Equal: Poverty and Inequality in Post-Apartheid South Africa, William Davidson Institute Working Papers Series wp739, William Davidson Institute at the University of Michigan Stephen M. Ross Business School.

Jung, H.S. and Thorbecke, E. (2001), The Impact of Public Education Expenditure on Human Capital, Growth, and Poverty in Tanzania and Zambia: A General Equilibrium Approach, International Monetary Fund. IMF Working Paper $\mathrm{WP} / 01 / 106$.

National Institute of Economic Policy (NIEP) (1996), Children, Poverty and Disparity Reduction in South Africa: Towards Fulfilling the Rights of South Africa's Children. Pretoria: Government Printer.

OECD. (2008), What are equivalence scales? OECD Social Policy Division. Downloaded at http://www.oecd.org/els/social on 10 February 2008.

Republic of South Africa, (1996), Report of the Lund Committee on Child and Family Support. August.

Statistics South Africa \& National Treasury (2007), A national poverty line for South Africa. 21 February. Available at http://www.treasury.gov.za

Statistics South Africa. (2007) Income and Expenditure of Households 2005. Dataset. Statistics South Africa, Pretoria.

Streak, J., Yu, D., and Van der Berg, S. (2009) Measuring Child Poverty in South Africa: Sensitivity to the Choice of Equivalence Scale and an Updated Profile. Social Indicators Research 94:2, 183-201

Woolard, I. (2002), Income inequality and poverty: methods of estimation and some policy applications for South Africa. Thesis Presented for the Degree of Doctor of Philosophy in the School of Economics, University of Cape Town.

Woolard, I, and Leibbrandt, M. (2006), Towards a Poverty Line for South Africa: Background Note. February. Southern Africa Labour and Development Research Unit, University of Cape Town. Commissioned by National 
Treasury and Statistics South Africa. Available at http://www.treasury.gov.za 
Appendix: Sectors grouped according to severity of the impact of the crisis

\begin{tabular}{|c|c|c|}
\hline Group & Sectors & $\begin{array}{c}\text { Number of } \\
\text { sectors }\end{array}$ \\
\hline $\begin{array}{l}\text { Group 1: (Non } \\
\text { affected sectors) }\end{array}$ & $\begin{array}{l}\text { Gold \& uranium ore mining } \\
\text { Food } \\
\text { Beverages \& tobacco }\end{array}$ & 3 \\
\hline $\begin{array}{l}\text { Group 2: Sectors } \\
\text { weakly affected }\end{array}$ & $\begin{array}{l}\text { Agriculture, forestry \& fishing } \\
\text { Textiles } \\
\text { Wearing apparel } \\
\text { Leather \& leather products } \\
\text { Footwear } \\
\text { Wood \& wood products } \\
\text { Paper \& paper products } \\
\text { Water supply } \\
\text { Furniture }\end{array}$ & 9 \\
\hline $\begin{array}{l}\text { Group 3: Sectors } \\
\text { mildly affected: }\end{array}$ & $\begin{array}{l}\text { Building construction } \\
\text { Electricity, gas \& steam } \\
\text { Basic non-ferrous metals } \\
\text { Metal products excluding machinery } \\
\text { Other industries } \\
\text { Basic chemicals } \\
\text { Printing, publishing \& recorded media } \\
\text { Other chemicals \& man-made fibres } \\
\text { Rubber products } \\
\text { Plastic products } \\
\text { Glass \& glass products } \\
\text { Non-metallic minerals } \\
\text { Wholesale \& retail trade } \\
\text { Catering \& accommodation services } \\
\text { Railway transport } \\
\text { Road transport } \\
\text { Transport via pipeline } \\
\text { Water transport } \\
\text { Air transport } \\
\text { Transport support services } \\
\text { Communication } \\
\text { Finance \& insurance } \\
\text { Business services } \\
\text { Medical, dental \& other health \& veterinary services } \\
\text { Community, social \& personal services }\end{array}$ & 31 \\
\hline
\end{tabular}

